\title{
Microbial safety and quality of edible oil examined at Ethiopian public health institute, Addis Ababa, Ethiopia: a retrospective study
}

\begin{abstract}
Background: Nowadays food safety is considered to be one of the most global public health concerns. Edible oil is one of the most popular types of food to be consumed in every Ethiopian house. Though, its safety is not emphasized. It is produced in Ethiopia from small scale production to large industry level and / or imported from other countries.

Objective: To evaluate microbial and hygienic quality of edible oil.

Methods: A six year retrospective study design was conducted from January 2010 to January 2015 on 125 edible oil samples which were examined at Ethiopian public health institute, food safety and public health microbiology research laboratory, Addis Ababa, Ethiopia. The data was extracted using developed format from a laboratory registration book. Edible oil samples were examined for the presence of yeast, mould, aerobic plate count, total coliforms, fecal coliforms and Escherichia coli (E.coli). Additionally, examination for the presence of pathogenic organisms like salmonella species, shigella species, and staphylococcus aureus (S. aureus) were also performed. Data was cleaned and entered to Microsoft XL and then exported to SPSS for statistical analysis and values of different parameters were expressed as the mean \pm standard error $( \pm$ S.E).
\end{abstract}

Results: One hundred twenty five edible oil samples were examined among which 62(48\%) samples were containing a varying number of bacteria and/or Moulds. Results given in Table1 shows that the aerobic plate count was detected in $46(35.6 \%)$, moulds $32(24.8 \%)$, Yeasts 4(3.1\%), total coliforms 6(4.5\%) samples. Fecal coliforms, E.coli and S.aureus were found only in one sample. None of the examined edible oil samples contain salmonella and shigella organisms.

Conclusion: Some isolated microorganism indicates unhygienic condition of the edible oil somewhere in its way from processing to packaging and market display. The average microbial load is not higher than $105 \mathrm{cfu} / \mathrm{ml}$ for Aerobic mesophillic bacteria and $104 \mathrm{cfu} / \mathrm{ml}$ for moulds. These concentrations may be able to cause health problems in individuals who consume without enough heat processing and also some of the food spoilage organisms, specially the moulds, can hasten the deterioration the edible oil.

Keywords: microbial quality, edible oil, food safety, microbial examination, aerobic plate count, yeast mould count, fecal coliform count
Volume 6 Issue 3 - 2018

\author{
Waktole Gobena, Samson Girma, Tesfaye \\ Legesse, Firehiwot Abera, Almaz Gonfa, \\ Redwan Muzeyin, Rahel Fekade,Tigist \\ Yohannes \\ Ethiopian Public Health Institute, Ethiopia
}

Correspondence: Waktole Gobena, Ethiopian Public Health Institute, Gulele, Tel 913377004, Emailwake22015@gmail.com

Received: December 27, 2017 | Published: May 17, 2018

\section{Introduction}

In the web of world's food supply oil crops and their oils have the highest rank and is the second most valuable commodity in the world food trade. ${ }^{1}$ The quality of edible oil is a measure of identity and quality. It is also related to the method of obtaining the oils from their source. ${ }^{2}$ In the developed world quality of edible oils are highly established and controlled but in developing countries like Ethiopia where food safety and quality are poor similarly edible oils are also contextually not of good quality and standard. The most common edible oils in Ethiopia are of two types: the imported and the one locally produced. The common edible oils currently in Ethiopian markets are vegetable oils such as palm oil, sesame seed oil, soya bean oil, sunflower seed oil and groundnut seed oil.

A number of parameters have been used to characterize the identity and edibility of oils. The microbial parameters include moulds, coliforms, E.coli, Aerobic mesophillic bacteria. ${ }^{3}$ Food born diseases are critical public health problems. Microorganisms are known to cause chemical changes in edible oil that lead to deterioration in the quality of the edible oil which can cause serious health impacts and or death. The lipolytic activity of fungus on the triglycerides of oils and fats used in cooking formulations causes rancidity, acidity, bitterness, soapiness and other off flavors. ${ }^{4}$ Microbial contamination of edible oil is the most common health risk. Food processors and handlers with very poor personal hygiene and inadequate knowledge of food safety and quality could be the source of pathogen. ${ }^{5}$ Fungi have been noted for their ability to survive in oil by producing the enzyme lipase. ${ }^{6}$ The ability of these fungi to produce spores helped them to survive the anaerobic nature of the oil, and the spores are resistant to heat. Some fungi are of health significance because of their ability to produce aflatoxin which is capable of inducing toxic syndromes especially cancer. ${ }^{7,5}$ Frying and cooking of the edible oil can reduce the microbial load to the minimum level, but the fact is that some individual consume this products raw. This may result, in addition to 
the deterioration of quality of edible oil, health risk in such individuals when the microbial load is high. ${ }^{8}$

In developing countries; where traditional methods of productions are employed for the extraction of edible oils by individuals who have little or no knowledge neither of modern aseptic production techniques nor of the microbiological implication of poor sanitation and storage methods, edible oils are prone to contamination by microorganisms found in the environment, raw materials and equipments used for the processing, production, as well as those used for storage and distribution of edible oils. ${ }^{9}$ According to ministry of trade and industry of Ethiopia there are around 27 large and medium scale edible oil processors and more than 1000 edible oil micro-processers that operate in rural and urban areas of the country. They often use outdated technology to crush oil seeds which are directly sold to consumers. These processors run their operations in their own backyard of their residential areas in complete absence of modern packaging materials which greatly leads to very low quality and safety of these edible oils. There have been so many studies that were conducted on microbial food quality and safety but the studies that were conducted on edible oil microbial quality in Ethiopia is very less.

\section{Study objective}

The objective of this study was to evaluate microbial safety and quality of edible oil examined at Ethiopian Public health institute from Jan 2010 to Jan 2015.

\section{Materials and method}

\section{Study area and design}

A six year retrospective study was conducted at Ethiopian Public Health Institute, food science and Nutrition, Food Safety and Public Health Microbiology research laboratory from Jan 2010 to Jan 2015 on one 125 edible oil samples those were from different areas of the country.

\section{Sampling technique and sampling procedure}

The samples were collected aseptically from different sites of the country by public health professionals or environmental health professionals for internal quality, official or regulatory purposes. The samples were transported to the laboratory being kept at dispensary temperature. After arriving in food and public health microbiology, the samples were checked consistently by microbiologists for sample quality, adequacy and for the general quality of the sample.

\section{Sample analysis}

Aerobic plate count: Aerobic Plate Count $/ \mathrm{APC} /$ at $30^{\circ} \mathrm{c} / 48 \mathrm{hrs}$ : About $25 \mathrm{ml}$ stock from the oil samples were dissolved in $225 \mathrm{ml}$ of sterile buffered peptone water. Five to six fold serial dilutions were made from each stock solution. A $1 \mathrm{ml}$ Aliquots of the dilutions of each sample were inoculated on plate count agar (PCA) using pour plate method. Each plate was kept at $30^{\circ} \mathrm{c}$ for 72 hours. After incubation plates with colony numbers from 25 to 300 were selected for counting the colonies. The results were expressed as colony forming units (cfu) per $\mathrm{ml} .^{10}$

Total coliform count: Total Coliforms count (TCC): About $25 \mathrm{ml}$ of the oil samples were diluted with $225 \mathrm{ml}$ of buffered peptone water and serially diluted by adding $1 \mathrm{ml}$ of 1:10 diluted sample up to $10^{-5}$. From each dilution $1 \mathrm{~m}$ of the sample was transferred to sterile Petri plate and a small amount of Trypton soy gar was added using pour plate method. Then after 1 hour it was overlaid with violet red bile salt agar and incubated at $37^{\circ} \mathrm{c}$. After 24 hour the plate with colony number 25 to 300 was counted and enumerated as presumptive Coliform count. Again five representative colonies were then transferred using wire loop to brilliant green broth and incubated at $37^{\circ} \mathrm{c}$ for the next 24 hours. After that tubes with gas production were considered as lactose fomenters and counted as positive for confirmed total Coliform count. Finally the number of positive tubes were multiplied by the number of presumptive counts and noted as number of total Coliform count per $\mathrm{ml}^{.11}$

Faecal coliform count: Fecal coliforms (FCC), E.coli $/ 44^{\circ} \mathrm{c}$ : In the case of faecal coliforms the Violet red bile salt agars was incubated at $44^{\circ} \mathrm{C}$ for 24 hours and then after presumptive results were enumerated. Using wire loop five colonies were again transferred to EC broth and gas production were over observed. The results were then rated as confirmed fecal coliforms. E.coli count: was done by transferring a loop full from E.coli broth to nutrient broth and then subjected to biochemical test. $^{12}$

Yeast and mould count: Mould and Yeast $/ 22^{\circ} \mathrm{c} / 5-7$ days: About $25 \mathrm{ml}$ of the original oil sample was mixed with $225 \mathrm{ml}$ of buffered peptone water and from this dilution $0.1 \mathrm{ml}$ was transferred to Rose Bengal agar and inoculated using spreading plate method and incubated at $30^{\circ} \mathrm{c}$ for 5 to 7 days. Then, yeast and moulds were enumerated and rated as $\mathrm{cfu} / \mathrm{ml} .^{13}$

Salmonella species and shigella species: about $25 \mathrm{ml}$ of the oil sample was mixed with $225 \mathrm{ml}$ of BPW and none selectively enriched for 24 hours. The next day, after 24 hour, it was transferred to selenite cystine broth for selective enrichment and incubated for 18 hours. Then a loop full of the sample was transferred to XLD agar, incubated at $37^{\circ} \mathrm{c}$ and after 24 hours the suspected colonies were subjected to biochemical test and the results were reported as present or absent. ${ }^{12}$

Data analysis: data was extracted from laboratory registration book using carefully developed format on Microsoft XL and then exported to SPSS (version 20) for statistical analysis and values of different parameters were expressed as mean \pm standard error $( \pm \mathrm{SE})$

\section{Result and discussion}

\section{Results}

One hundred twenty five edible oil samples were examined among which $62(48 \%)$ were containing a varying number of bacteria and/ or Moulds. Table1and 2 shows that the Aerobic mesophilic bacterial count were detected in $46(36.8 \%)$ of the examined edible oil samples with a mean count of $2.61 \times 10^{4} \pm 1.47 \times 10^{4} \mathrm{cfu} / \mathrm{ml} .39(31.2 \%)$ and $12(9.6 \%)$ of edible oil samples contain moulds and yeast with a mean count of $3.2 \times 10^{4} \pm 4.48 \times 10^{2} \mathrm{cfu} / \mathrm{ml}$ and $3.2 \times 10^{4} \pm 2.62 \times 10^{2} \mathrm{cfu} /$ $\mathrm{ml}$ respectively. Total coliforms were detected in $10(8 \%)$ with mean count of $6.6 \times 10^{4} \pm 5.4 \times 10^{4} \mathrm{cfu} / \mathrm{ml}$. Fecal coliforms, E.coli and S.aureus were detected in only one sample and none of the examined samples contain pathogenic microorganisms salmonella species and shigella species (Table $1 \& 2$ ). 
Table 1 statistical results of different microbial groups/ml of examined edible oil samples

\begin{tabular}{lllll}
\hline Type of test/organisms & Minimum & Maximum & Mean & \pm Standard error \\
\hline $\begin{array}{l}\text { Aerobic plate count } \\
\text { at } 37^{\circ} \mathrm{C} / 48 \mathrm{hrs} .\end{array}$ & $<1 \times 10^{1}$ & $1.56 \times 10^{6}$ & $2.61 \times 10^{4}$ & $1.47 \times 10^{4}$ \\
Mould at $22^{\circ} \mathrm{C} / 7$ days & $<1 \times 10^{1}$ & $4 \times 10^{3}$ & $4.1 \times 10^{4}$ & $4.48 \times 10^{2}$ \\
Yeast at $22^{\circ} \mathrm{C} / 7$ days & $<1 \times 10^{1}$ & $1 \times 10^{4}$ & $3.2 \times 10^{4}$ & $2.62 \times 10^{2}$ \\
Total coliforms & $<1 \times 10^{1}$ & $7.4 \times 10^{6}$ & $6.6 \times 10^{4}$ & $5.8 \times 10^{4}$ \\
Faecal coliforms & $<1 \times 10^{1}$ & $1.6 \times 10^{4}$ & $1.26 \times 10^{2}$ & $1.26 \times 10^{2}$ \\
E.coli & $<1 \times 10^{1}$ & $3.28 \times 10^{3}$ & - & - \\
S.aureus & $<1 \times 10^{1}$ & $1.3 \times 10^{2}$ & - & - \\
Salmonella and Shigella & $\mathrm{A}$ & & & \\
\hline
\end{tabular}

A, absent; $<1 \times 101$, no detectable colony per ml

Table 2 Frequency distribution of different microbial group $/ \mathrm{ml}$ of examined edible oil samples.

\begin{tabular}{lllllll}
\hline \multirow{2}{*}{ Intervals } & APC & Mould & yeast & coliforms & Fecal coliforms & E.coli \\
\cline { 2 - 6 } & No $\%$ & No $\%$ & No $\%$ & No $\%$ & No & No \\
\hline$<10^{1}$ & 7963.2 & 8668.8 & 11390.4 & 11592 & 124 & 124 \\
$10^{1}-10^{2}$ & 2016 & 2116.8 & 97.2 & 21.6 & - & - \\
$10^{2}-10^{3}$ & 1814.4 & 1310.4 & 10.8 & 32.4 & - & - \\
$10^{3}-10^{4}$ & 108 & 54 & 21.6 & 21.6 & 1 & 1 \\
$10^{4}-10^{5}$ & 32.4 & - & - & 10.8 & - & - \\
$10^{5}-10^{6}$ & 21.6 & - & - & 21.6 & - & - \\
\hline
\end{tabular}

$<10^{1}$ no detectable colony per $\mathrm{ml}$ of sample

\section{Discussion}

The micro flora of edible oil reflects the quality of oil, the sanitary conditions of equipment used to manufacture the oil and the environmental and sanitary conditions during packaging and handling of such product. ${ }^{14}$ In this study $46(36.8 \%)$ of the samples were contaminated by Aerobic mesohylic bacteria with a mean value of $2.61 \times 10^{4} \pm 1.47 \times 10^{4} \mathrm{cfu} / \mathrm{ml}$. In previous study conducted in Nigerian nearly similar results were recorded ${ }^{15}$ with mean count of $1.61 \times 10^{4}$ to $9.4 \times 10^{4} \mathrm{cfu} / \mathrm{ml}$. This finding is slightly greater than the study conducted at Gonder town of Ethiopia which found highest aerobic plate count of $4.95 \times 10^{3} \pm 2.76 \times 10^{3} \mathrm{cfu} / \mathrm{ml}$. Most of the time Aerobic mesohpilic organisms are responsible for the deterioration of foods including edible oil and especially some microorganisms produce lipase enzyme which plays an important role in the deterioration edible oil. ${ }^{16}$

Total coliforms counts (NMKL technique) were carried out as hygiene indicators. Total coliforms were detected in $10(8.0 \%)$ the edible oil samples with a mean coliform count of $6.6 \times 10^{4} \pm 2.62 \times 10^{2} \mathrm{cfu} / \mathrm{ml}$. Even though finding of coliforms in edible oil is rare due to its anaerobic nature; total coliforms are indicators of unhygienic production area and packaging material. In a study conducted in Nigeria coliforms were not isolated from both branded and non branded vegetable edible oil. ${ }^{17}$ In this study fecal coliforms and E.coli were detected from only one sample with microbial count of $1.6 \times 10^{4}$ and $3.28 \times 10^{3} \mathrm{cfu} / \mathrm{ml}$ respectively. Faecal coliforms are an indication for faecal pollution and additionally E.coli is an index organism and its presence indicates possible presence of pathogenic enterobacteriacea. ${ }^{18}$

Staphylococcus aureus was isolated from only one sample with a total count of $1.3 \times 10^{2} \mathrm{cfu} / \mathrm{ml}$. Similar results were found from studies conducted in Nigeria by Okechalu et al. and from Gonder by Lideya T. et al. The presence of S.aureus is an indicator of poor hygienic practice. This organism has capable of producing enterotoxin; it involves in food poisoning and is noted to survive for extended periods in hostile environments. It could cause gastroenteritis in the individuals if the oil is consumed raw or under cooked.

The findings of this study shows that the mould and yeast results are found to be in a mean count of $4.1 \times 10^{4} \pm 4.48 \times 10^{2} \mathrm{cfu} / \mathrm{ml}$ and $3.2 \times 10^{4} \pm 2.62 \times 10^{2} \mathrm{cfu} / \mathrm{ml}$ respectively. In this study mould and yeast count were nearly similar with the study conducted in Nigeria by okechalu et al. and Gonder town, Ethiopia by Lideya T. et al with mean count of $4.43 \times 10^{3} \pm 1.25 \times 10^{4} \mathrm{cfu} / \mathrm{ml}$. In a similar study conducted in Nigeria the presence of high load of Yeasts and Mould in edible oil causes deterioration by secreting extra cellular lipases enzyme. This enzyme breaks down ester bonds in lipid molecules and liberates diglycerides, monoglycerides, and glycerols, Free fatty acids and results in increment of free fatty acid values of edible oil leading to deterioration. ${ }^{19}$

\section{Conclusion}

In conclusion the isolated microorganisms in this study include pathogenic bacteria, fungi and indicator organisms. Some isolated microorganism indicates unhygienic condition of the oil somewhere in its way from processing to packing and market display. Even though the average microbial load is not high (above $10^{5} \mathrm{cfu} / \mathrm{ml}$ for Aerobic mesophillic bacteria and $10^{4} \mathrm{cfu} / \mathrm{ml}$ for moulds), by these concentrations it may be able to cause health problems in individuals who consume without enough heat processing and also some of the food spoilage organisms, specially the moulds, can hasten the deterioration of the edible oil. Most of the time microbial spoilage of oil remains unaware and then public awareness is recommended. On the other hand strengthening quality control body and further study utilizing larger sample size is also important.

\section{Ethics approval and consent to participate}

Not applicable. 


\section{Human and animal rights}

No animals or humans were used for studies that are base of this research.

\section{Consent for publication}

Not applicable.

\section{Acknowledgements}

We greatly appreciate Ethiopian Public Health Institute for supporting this study. We also extend our thanks to public health officers who collect and brought edible oil samples to our laboratory.

\section{Conflict of interest}

The author declares no conflict of interest.

\section{References}

1. Abulude FO, Ogunkoya MO, Ogunleye RF. Storage properties of two Nigerian oil seeds Jatropha curcas (physic Nut) and Helianthus annuus (sunflower). Am J Food Techinol. 2007;2(3):207-211.

2. Codex Alimentarius. Standard for named vegetable oils. CODEX STAN 210-1999. Amendment. 2001;8:11-25.

3. Odoh CK, Amapu TY, Orjiakor IP, et al. Assessment of mold contamination and physicochemical properties of crude palm oil sold in Jos, Nigeria. Food Scie \& Nutr 2017;5(2):310-316.

4. Okechalu JN, Dashen MM, Manko P, et al. Microbiological quality and chemical characteristics of palm oil sold within Jos Metropolis, Plateau State, Nigeria. J Microbiol Biotech Research 2011;1(2):107-112.

5. http://apps.who.int/iris/handle/10665/39610

6. Ekwu A, Nwagu FC. Effect of processing on the quality of cashew nut oils. J Sci Agric Food Tech Environ. 2004;4:105-110.

7. Nwanekezi EC, Oyeagba RA. Effect of Spoilage Microorganisms on the physicochemical properties of African Pear Fruit Oil. J Food Agri Environ. 2007;5:90-93.
8. Okogbenin OB, Okogbenin EA, Okunwaye T, et al. Isolation of food pathogens from freshly milled palm oil and the effect of sterilization on oil quality parameters. Journal of Food Security. 2014;2(2):65-71.

9. Teshome k, Kokeb B, Habtahwi R. The Ethiopian perception on food safety system. Adv. Food sci.techinol.2014; 2(9):260-268.

10. Nordic committee on food analysis (NMKL). Aerobic microorganisms. Determination in food at $37^{\circ}, 25^{\circ}$ by colony count method. 5th information supplement; 2013.

11. Nordic committee on food analysis (NMKL). Enterobacteriaceae determination in foods and feeds. NMKL no.144, 3rd information supplement; 2005.

12. Nordic committee on food analysis (NMKL). Salmonella detection in food and feed. NMKL no.71, 5th information supplement; 2005.

13. Nordic committee on food analysis (NMKL). Mould and yeast determination in foods and feed. NMKL no.98, 4th information supplement; 2005.

14. World health organization. Food safety and food borne diseases and value chain management for food safety. "Forging links between agriculture and health" CGIAR on agriculture and health meeting in WHO/HQ; 2007.

15. Okechalu JN, Dashen MM, Manko P, et al. Microbiological quality and chemical characteristics of palm oil sold within Jos Metropolis, Plateau State, Nigeria. J. Microbiol. Biotech Research. 2011;1(2):107-112.

16. Lideya T, Samuel S, Alle M. Microbial quality and chemical characteristics evaluation of edible oil sold at gondar town markets, north west Ethiopia. International Journal of Modern Chemistry and Applied Science. 2015;2(4):238-247.

17. Chabiri SA, Hati SS, Dimari GA, et al. Comparative Quality Assessment of Branded and Unbranded Edible Vegetable Oils in Nigeria. The Pacific Journal of Science and Technology. 2009;10(2):927-934.

18. Tortorelo ML. Indicator organisms for safety and quality-uses and methods for detection: minireview. J AOAC Int. 2003;86(6):1208-1217.

19. Ezediokpu Marycolette N, Okerentugba, Omorodion, et al. Quality assessment of unbranded palm oil distributed in five local markets in port Harcourt, Rivers state Nigeria. IOSR Journal of Agriculture and Veterinary Science (IOSR-JAVS). 2015;8(4):27-32. 